\title{
Zinc(II) Coordination Frameworks Based on Benzobisimidazole: The Role of the Methyl Substituent
}

\author{
Hana Bunzen, ${ }^{*[a]}$ Farah Mahmood, ${ }^{[a]}$ Maciej Grzywa, ${ }^{[a]}$ and Dirk Volkmer ${ }^{[a]}$
}

\begin{abstract}
Three $\mathrm{Zn}$ " coordination frameworks (CFs) based on benzobisimidazole were prepared by utilizing organic ligands containing methyl groups in the 2-position of the imidazole rings. The molecular structures of the prepared CFs were revealed by single-crystal XRD. The influence of the methyl group on the crystal packing motifs of the materials was investigated
\end{abstract}

\section{Introduction}

Imidazole and its derivatives have been extensively studied as ligands for preparing various coordination materials. Among others, zeolitic imidazolate frameworks (ZIFs) - a class of metalorganic frameworks (MOFs) - are the most prominent. ${ }^{[1]} \mathrm{ZIFs}$ show many similarities to zeolites. Their metal-imidazolatemetal angles are similar to the $145^{\circ} \mathrm{Si}-\mathrm{O}-\mathrm{Si}$ angle commonly observed in zeolites. ${ }^{[1 a]}$ Due to their remarkable thermal and chemical stability, ZIFs have received a lot of attention over the past few years and have been considered for various applications in many different fields including gas separation, catalysis and sensing. ${ }^{[2]}$

MOFs are known for high design versatility. ${ }^{[3]}$ For instance, even a small structural nuance, such as replacing the hydrogen atom in the 2-position of the imidazole ring by a methyl group, can cause dramatic changes to the structure of the coordination framework (Scheme 1). ${ }^{[1 a]}$ Another example is the comparison of ZIFs based on imidazole and benzimidazole. Due to the bulky

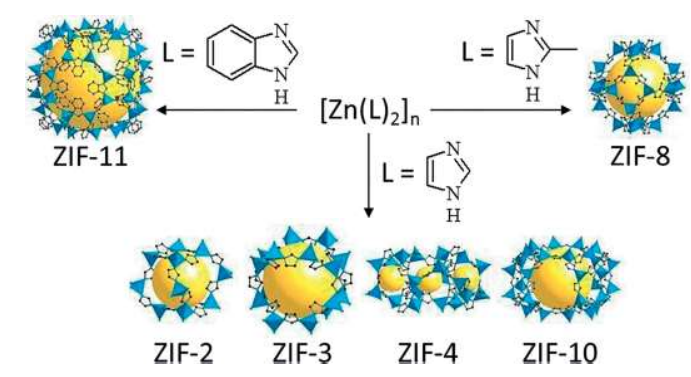

Scheme 1. Examples of the design versatility of imidazole-based ligands resulting in formation of various ZIFs. Scheme adapted from ref. ${ }^{[1]}$

[a] Chair of Solid State and Materials Chemistry, Institute of Physics, University of Augsburg,

Universitätsstrasse 1, 86159 Augsburg, Germany

E-mail: hana.bunzen@physik.uni-augsburg.de and compared to structurally related compounds without methyl groups in the 2-position of the imidazole rings, which were prepared under the same or very similar reaction conditions. The thermal stability of the prepared CFs was investigated by variable-temperature powder XRD and thermogravimetric analysis, and their photoluminescence properties are reported.

side part of the benzimidazole ligand, a completely different framework is obtained than when imidazole is used as ligand (Scheme 1). ${ }^{[1 \mathrm{a}]}$

Although imidazole and its derivatives have been extensively used for preparing MOFs, ${ }^{[1]}$ bis-imidazoles as ligands for coordination materials have received much less attention. Only few coordination frameworks (CFs) based on benzobisimidazole (1) have been reported. These include a $\mathrm{Cu}^{\text {II }} \mathrm{CF}$ showing promising applications in the capture of $\mathrm{CO}_{2}{ }^{[4]} 2 \mathrm{D}$-layered $\mathrm{Zn}^{\text {"I }}$ and $\mathrm{Cd}^{\prime \prime}$ frameworks exhibiting selective solvent adsorption, ${ }^{[5]}$ and two 3D frameworks containing $\mathrm{Zn}$ " and Coll ions recently reported by us. $^{[6]}$ Nevertheless, CFs based on benzobisimidazole ligands featuring methyl groups in the 2-position of the imidazole rings have not been reported until now. In this work, we synthesized compounds $\mathbf{2}$ and $\mathbf{3}$ (Scheme 2) and used them as ligands for preparing Zn" CFs CF-1, CF-2 and CF-3 (Scheme 3).
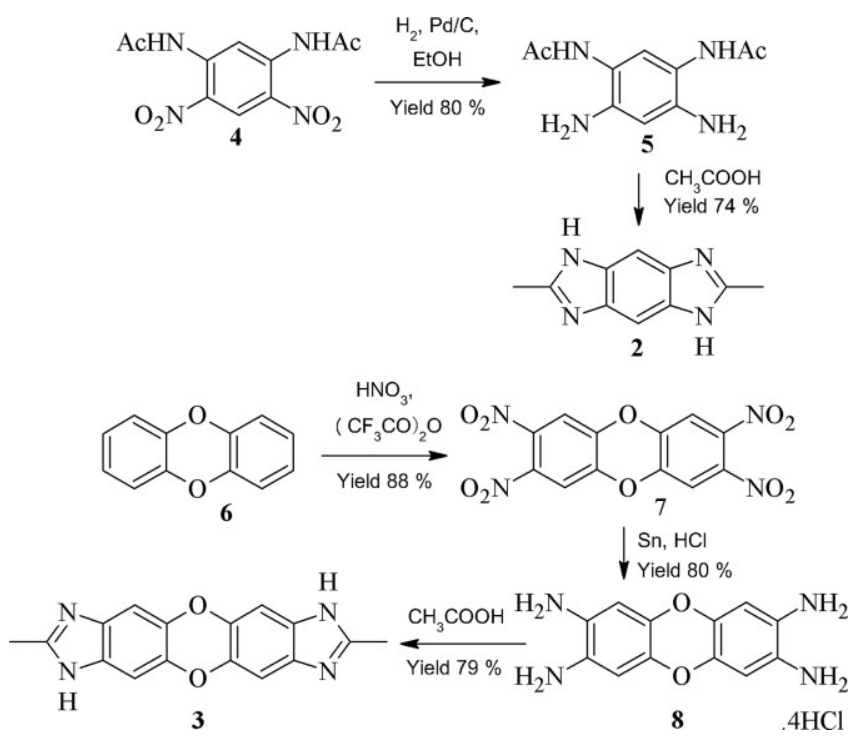

Scheme 2. Synthesis of ligands $\mathbf{2}$ and $\mathbf{3}$ 


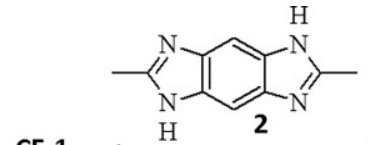

$\mathrm{CF}-1 \stackrel{\mathrm{H} \quad 2}{\longleftarrow}$

$\left(\mathrm{ZnSO}_{4}\right.$ or $\mathrm{Zn}\left(\mathrm{NO}_{3}\right)_{2}$ in DMSO)

CF-2 $\left(\mathrm{ZnCl}_{2}\right.$ in DMF)

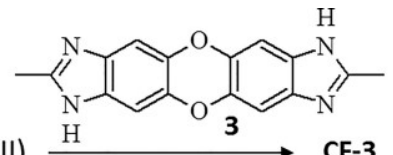

\section{$\mathrm{Zn}(\mathrm{II})$}

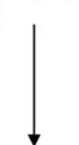

CF-4 $\left(\mathrm{ZnSO}_{4}\right.$ or $\mathrm{Zn}\left(\mathrm{NO}_{3}\right)_{2}$ in $\left.\mathrm{DMSO}\right)$

CF-5 $\left(\mathrm{ZnCl}_{2}\right.$ in DMSO)

Scheme 3. Synthesis of Zn" CFs CF-1 $\left\{\left[\mathrm{Zn}\left(\mathrm{SO}_{4}\right)\left(\mathrm{C}_{10} \mathrm{H}_{10} \mathrm{~N}_{4}\right)\right] \cdot\left(\mathrm{C}_{2} \mathrm{H}_{6} \mathrm{OS}\right)_{0.35}\right\}, \mathrm{CF}-\mathbf{2}$ $\left\{\left[\mathrm{ZnCl}\left(\mathrm{C}_{10} \mathrm{H}_{8} \mathrm{~N}_{4}\right)_{0.5}\left(\mathrm{C}_{3} \mathrm{H}_{7} \mathrm{NO}\right)\right]\right\}, \mathrm{CF}-3\left\{\left[\mathrm{ZnCl}\left(\mathrm{C}_{16} \mathrm{H}_{10} \mathrm{~N}_{4} \mathrm{O}_{2}\right)_{0.5}\left(\mathrm{C}_{3} \mathrm{H}_{7} \mathrm{NO}\right)\right] \cdot\left(\mathrm{C}_{3} \mathrm{H}_{7} \mathrm{NO}\right)\right\}$, CF-4 $\left\{\left[\mathrm{Zn}\left(\mathrm{SO}_{4}\right)\left(\mathrm{C}_{8} \mathrm{H}_{6} \mathrm{~N}_{4}\right)\right] \cdot\left(\mathrm{C}_{2} \mathrm{H}_{6} \mathrm{OS}\right)\right\}^{[6]}$ and CF-5 $\left\{\left[\mathrm{ZnCl}\left(\mathrm{C}_{8} \mathrm{H}_{4} \mathrm{~N}_{4}\right)_{0.5}\left(\mathrm{C}_{2} \mathrm{H}_{6} \mathrm{O}_{2} \mathrm{~S}\right)\right]\right\}^{[5]}$ based on ligands $1\left(\mathrm{C}_{8} \mathrm{H}_{6} \mathrm{~N}_{4}\right), \mathbf{2}\left(\mathrm{C}_{10} \mathrm{H}_{10} \mathrm{~N}_{4}\right)$ and $\mathbf{3}\left(\mathrm{C}_{16} \mathrm{H}_{12} \mathrm{~N}_{4} \mathrm{O}_{2}\right)$.

Inspired by ZIFs and the fact that small modifications in the chemical structure of the ligands cause tremendous changes to the structure of the resulting $C F$, we studied the influence of the methyl group (ligand 1 vs. ligand 2, Scheme 3 ) and the size of the ligand (ligand $\mathbf{2}$ vs. ligand $\mathbf{3}$, Scheme 3 ) on the molecular structure and material properties of the prepared $\mathrm{Zn}$ "l CFs. The obtained results were compared with those of $\mathrm{Zn}$ " CFs reported in the literature ${ }^{[5,6]}$ that were prepared under the same or very similar reaction conditions starting from compound $\mathbf{1}$ as ligand instead of ligand $\mathbf{2}$ or $\mathbf{3}$ (Scheme 3 ).

\section{Results and Discussion}

\section{Ligand Synthesis}

Ligand 2 (1,5-dihydro-2,6-dimethylbenzo[1,2-d:4,5- $d^{\prime}$ ]diimidazole) was synthesized in two steps starting from 1,3-diamino4,6-diacetamidobenzene (4, Scheme 2 ), which was prepared according to the previously reported synthesis. ${ }^{[7]}$ Ligand 3 (1,7dihydrido-2,8-dimethyl-[1,4]dioxino[2,3-f:5,6- $\left.f^{\prime}\right]$ bisbenzimidazole) was synthesized in three steps starting from dibenzo-1,4dioxin (6, Scheme 2). The nitration of dibenzo-1,4-dioxin and subsequent reduction to 2,3,7,8-tetraaminodibenzo-1,4-dioxin tetrahydrochloride (8) were carried out by following the recently reported reaction procedures. ${ }^{[8]}$ The final step, that is, the formation of the 2-methylimidazole ring, was achieved in both cases $(\mathbf{2}, \mathbf{3})$ by treating the amine $(\mathbf{5}, \mathbf{8})$ with acetic acid at elevated temperature.

At room temperature, compound $\mathbf{2}$ is soluble in DMSO, DMF and $\mathrm{N}, \mathrm{N}$-dimethylacetamide, whereas compound $\mathbf{3}$ is only partially soluble in these solvents. In fact, at room temperature, ligand $\mathbf{3}$ is insoluble in most organic solvents, with the exception of trifluoroacetic acid.

\section{Synthesis of Coordination Frameworks}

Compounds $2\left(\mathrm{C}_{10} \mathrm{H}_{10} \mathrm{~N}_{4}\right)$ and $3\left(\mathrm{C}_{16} \mathrm{H}_{12} \mathrm{~N}_{4} \mathrm{O}_{2}\right)$ were combined with $\mathrm{Zn}$ " ions to prepare $\mathrm{Zn}$ " CFs. In order to compare the structure and properties of the final products with those of compounds based on benzobisimidazole (1) reported in the literature (Scheme 3), the synthesis was carried out under the same or very similar reaction conditions. By treating ligand $\mathbf{2}$ with
zinc(II) ions in DMSO, CF-1 $\left\{\left[\mathrm{Zn}\left(\mathrm{SO}_{4}\right)\left(\mathrm{C}_{10} \mathrm{H}_{10} \mathrm{~N}_{4}\right)\right] \cdot\left(\mathrm{C}_{2} \mathrm{H}_{6} \mathrm{OS}\right)_{0.35}\right\}$ was obtained and was studied as a structural analogue to the material recently reported by us (CF-4 in Scheme 3). ${ }^{[6]}$ There are two synthetic routes to obtain CF-1. In the first procedure, $\mathrm{Zn}\left(\mathrm{NO}_{3}\right)_{2} \cdot 6 \mathrm{H}_{2} \mathrm{O}$ and ligand 2 were dissolved in DMSO and the mixture was heated at $120{ }^{\circ} \mathrm{C}$ for $3 \mathrm{~d}$. In this synthetic route, the sulfate ions are produced in situ as a result of the thermal decomposition of DMSO. This process slowed down the nucleation rate, and thus large single crystals were obtained (Figure 1a). However, the reaction yield was quite low (ca. $13 \%$ ). Therefore, a second synthetic route was developed to obtain bulk quantities of CF-1. In the second route, $\mathrm{ZnSO}_{4} \cdot \mathrm{H}_{2} \mathrm{O}$ was used as the metal salt instead of $\mathrm{Zn}\left(\mathrm{NO}_{3}\right)_{2} \cdot 6 \mathrm{H}_{2} \mathrm{O}$, and the reaction mixture was heated at $140{ }^{\circ} \mathrm{C}$ for $1 \mathrm{~d}$. Interestingly, the crystal morphology of CF-1 differed depending on the synthetic route. The crystals obtained with $\mathrm{Zn}\left(\mathrm{NO}_{3}\right)_{2} \cdot 6 \mathrm{H}_{2} \mathrm{O}$ were large and leaf-shaped (Figure 1a), whereas those synthesized from $\mathrm{ZnSO}_{4} \cdot \mathrm{H}_{2} \mathrm{O}$ were smaller and block-shaped (Figure $1 \mathrm{~b}$ ). Comparison of the X-ray powder diffraction (XRPD) data of samples from these two methods revealed that identical crystalline materials were obtained by both approaches (Figure S9). Frameworks CF-2 $\left\{\left[\mathrm{ZnCl}\left(\mathrm{C}_{10} \mathrm{H}_{8} \mathrm{~N}_{4}\right)_{0.5}\left(\mathrm{C}_{3} \mathrm{H}_{7} \mathrm{NO}\right)\right]\right\}$ and CF-3 $\left\{\left[\mathrm{ZnCl}\left(\mathrm{C}_{16} \mathrm{H}_{10} \mathrm{~N}_{4} \mathrm{O}_{2}\right)_{0.5}\left(\mathrm{C}_{3} \mathrm{H}_{7} \mathrm{NO}\right)\right] \cdot\left(\mathrm{C}_{3} \mathrm{H}_{7} \mathrm{NO}\right)\right\}$ were prepared by reaction of ligands $\mathbf{2}$ and $\mathbf{3}$ with anhydrous zinc(II) chloride in DMF at $130^{\circ} \mathrm{C}$ for $3 \mathrm{~d}$. The two materials were prepared under the same conditions to reveal the influence of ligand size on the structure and material properties.
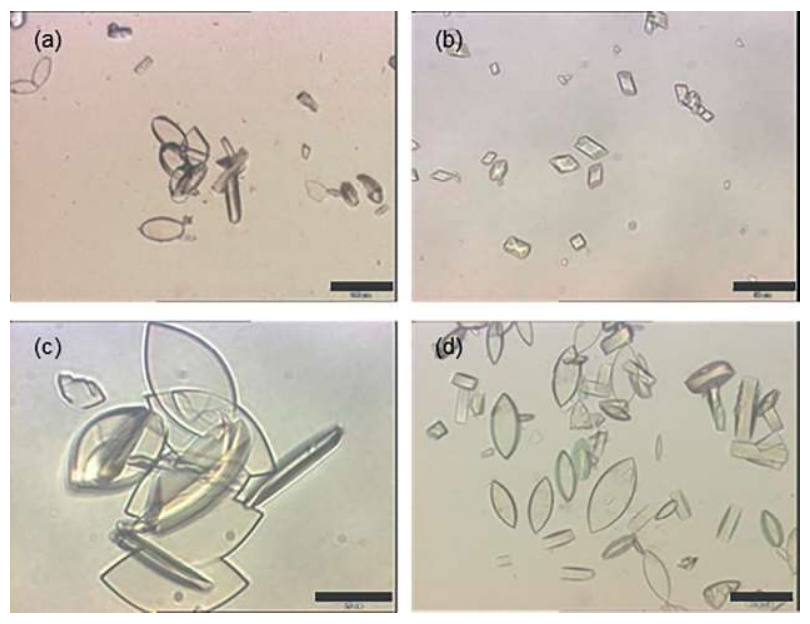

Figure 1. Optical micrographs of (a, b) CF-1, (c) CF-2 and (d) CF-3; scale bars: (a) $100 \mu \mathrm{m}$, (b) $50 \mu \mathrm{m}$, (c) $50 \mu \mathrm{m}$ and (d) $100 \mu \mathrm{m}$.

\section{Single-Crystal X-ray Structure Analysis}

In all three cases (i.e. CF-1, CF-2 and CF-3), colourless single crystals of an uncommon leaf-shaped morphology were isolated (Figure 1a, c, d) and used for the single-crystal X-ray structure analysis. Such leaf-shaped crystal morphology was recently observed for a ZIF prepared from $\mathrm{Zn}^{\prime \prime}$ and 2-methylimidazole (ZIF-L). ${ }^{[9]}$ ZIF-L is a pseudopolymorph of ZIF-8 (shown in Scheme 1) and has a unique 2D-layered structure formed by the stacking of 2D nanosheets along the $c$ direction and stabilized by hydrogen bonds between adjacent imidazole ligands. 
Similarly, CF-1, CF-2 and CF-3, based on ligands containing 2methylimidazole units, were found to be 2D-layered CFs.

Before discussing the structure of CF-1 $\left\{\left[\mathrm{Zn}\left(\mathrm{SO}_{4}\right)\left(\mathrm{C}_{10} \mathrm{H}_{10} \mathrm{~N}_{4}\right)\right]\right.$. $\left.\left(\mathrm{C}_{2} \mathrm{H}_{6} \mathrm{OS}\right)_{0.35}\right\}$, it is prudent to review that of previously reported $\mathrm{Zn}$ "l CF CF-4 $\left\{\left[\mathrm{Zn}\left(\mathrm{SO}_{4}\right)\left(\mathrm{C}_{8} \mathrm{H}_{6} \mathrm{~N}_{4}\right)\right] \cdot\left(\mathrm{C}_{2} \mathrm{H}_{6} \mathrm{OS}\right)\right\}_{,}{ }^{[6]}$ which served as an inspiration for the synthesis of CF-1. Both CFs were prepared under the same reaction conditions, except for the fact that different ligands were used (Scheme 3). Framework CF-4 is a $3 \mathrm{D} C F$ that contains $\mu_{2}$-benzobisimidazole and $\mu_{2}$-sulfate bridges (each $\mathrm{Zn}$ " ion is coordinated to two $\mathrm{N}$ atoms of two different ligand molecules, and the remaining two coordination sites are occupied by the $\mathrm{O}$ atoms of two different sulfate ions to form a distorted tetrahedral arrangement). Similarly, CF-1, which was prepared from methyl-containing ligand 2 $\left(\mathrm{C}_{10} \mathrm{H}_{10} \mathrm{~N}_{4}\right)$ instead of benzobisimidazole $\left(1, \mathrm{C}_{8} \mathrm{H}_{6} \mathrm{~N}_{4}\right)$, contains $\mu_{2}$-bisimidazole ligands and $\mu_{2}$-sulfate bridges. However, the structure of CF-1 is different from that of CF-4 (see Figure 2). Framework CF-1 crystallizes in the monoclinic space group $\mathrm{C} 2 / \mathrm{m}$ (Table 1), and the local coordination geometry around the $\mathrm{Zn}^{\mathrm{II}}$ ions in CF-1 can be described as a distorted tetrahedron. Each $\mathrm{Zn}^{\text {II }}$ ion is coordinated by two different molecules of $\mathbf{2}$ through their $\mathrm{N}$ donor atoms and two sulfate anions through their $\mathrm{O}$ donor atoms. These sulfate anions form $\mu_{2}$ bridges in such a way that each two $\mathrm{Zn}$ "l ions are connected to each other by two sulfate bridges. This connectivity pattern results in 2Dlayered CF CF-1 (Figure S13), in contrast to the reported 3D CF CF-4. ${ }^{[6]}$ Since both CFs were prepared under the same reaction conditions, the fact that we obtained a different network when using ligand $\mathbf{2}$ instead of $\mathbf{1}$ must be attributed to the presence of the methyl group in ligand $\mathbf{2}$.

Additionally, the single-crystal $\mathrm{X}$-ray structure analysis revealed voids between the layers of CF-1 (Figure S13), which are filled with solvent molecules ( 0.35 molecules of DMSO per

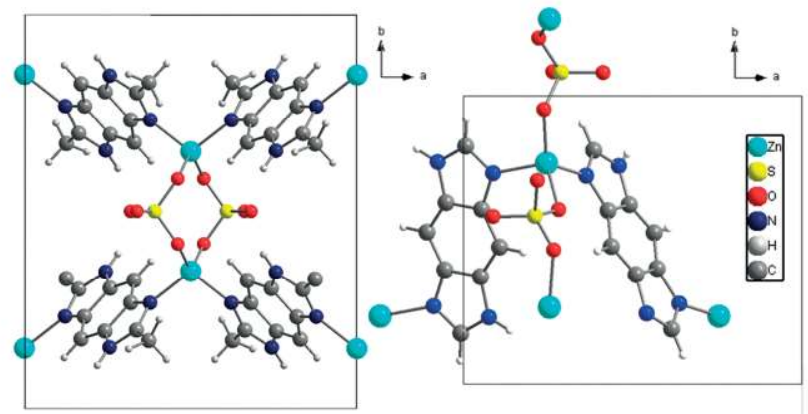

Figure 2. Ball-and-stick representation of the different coordination environments around the $\mathrm{Zn}^{\text {II }}$ ions in CF-1 (left) and CF-4 ${ }^{[6]}$ (right).

ligand molecule). The possibility to remove the solvent and to prepare a material with permanent porosity is discussed in detail below.

Frameworks CF-2 $\left\{\left[\mathrm{ZnCl}\left(\mathrm{C}_{10} \mathrm{H}_{8} \mathrm{~N}_{4}\right)_{0.5}\left(\mathrm{C}_{3} \mathrm{H}_{7} \mathrm{NO}\right)\right]\right\}$ and CF-3 $\left\{\left[\mathrm{ZnCl}\left(\mathrm{C}_{16} \mathrm{H}_{10} \mathrm{~N}_{4} \mathrm{O}_{2}\right)_{0.5}\left(\mathrm{C}_{3} \mathrm{H}_{7} \mathrm{NO}\right)\right] \cdot\left(\mathrm{C}_{3} \mathrm{H}_{7} \mathrm{NO}\right)\right\}$, both prepared by reaction of the corresponding ligands with anhydrous $\mathrm{ZnCl}_{2}$ in DMF at elevated temperature, crystallize in the monoclinic space group $P 2_{1} / n$ (Table 1). During heating, DMF decomposes to form dimethylamine, which acts as a base and is responsible for deprotonating the $\mathrm{NH}$ groups of the ligands. Therefore, all four $\mathrm{N}$ donor atoms are available to coordinate to $\mathrm{Zn}$ " and the ligand is $\mu_{4}$-bridging. Despite the elongated structure of ligand $\mathbf{3}$ compared to ligand $\mathbf{2}$, the coordination environment of $\mathrm{Zn}$ " in CF-3 is the same as in CF-2 and can be described as a distorted tetrahedron. Each $\mathrm{Zn}$ " ion is coordinated to two different ligand molecules. The two remaining coordination sites are occupied by a chloride anion and one molecule of DMF. Thus, adjacent

Table 1. Single-crystal and structure refinement parameters of CF-1, CF-2 and CF-3.

\begin{tabular}{|c|c|c|c|}
\hline & CF-1 & CF-2 & CF-3 \\
\hline Empirical formula & $\mathrm{C}_{10} \mathrm{H}_{10} \mathrm{~N}_{4} \mathrm{O}_{4} \mathrm{~S}_{2} \mathrm{Zn} \cdot\left(\mathrm{C}_{2} \mathrm{H}_{6} \mathrm{OS}\right)_{0.35}$ & $\mathrm{C}_{8} \mathrm{H}_{11} \mathrm{CIN}_{3} \mathrm{OZn}$ & $\mathrm{C}_{11} \mathrm{H}_{12} \mathrm{ClN}_{3} \mathrm{O}_{2} \mathrm{Zn} \cdot \mathrm{C}_{3} \mathrm{H}_{7} \mathrm{NO}$ \\
\hline Formula weight & 464.84 & 266.02 & 392.15 \\
\hline$T[\mathrm{~K}]$ & $300(2)$ & $100(2)$ & $301(2)$ \\
\hline$\lambda[\AA]$ & 0.71073 & 0.71073 & 0.71073 \\
\hline Crystal system & monoclinic & monoclinic & monoclinic \\
\hline Space group & C2/m (no. 12) & $P 2_{1} / n$ (no. 14) & $P 2_{1} / n$ (no. 14) \\
\hline$a[\AA]$ & $14.0577(5)$ & $11.1259(5)$ & $12.6802(11)$ \\
\hline$b[\AA]$ & $14.5587(5)$ & $9.2498(4)$ & $8.7301(8)$ \\
\hline$c[\AA]$ & $9.0439(3)$ & $11.3999(5)$ & $16.6169(14)$ \\
\hline$\beta\left[^{\circ}\right]$ & $119.0010(10)$ & $109.651(2)$ & $98.361(3)$ \\
\hline$V\left[\AA^{3}\right]$ & $1618.85(10)$ & $1104.86(8)$ & $1819.9(3)$ \\
\hline$Z$ & 4 & 4 & 4 \\
\hline$\varrho_{\text {calcd. }}\left[\mathrm{mg} \mathrm{m}^{-3}\right]$ & 1.907 & 1.599 & 1.431 \\
\hline Absorption coeff. [mm $\left.\mathrm{mm}^{-1}\right]$ & 1.880 & 2.436 & 1.514 \\
\hline$F(000)$ & 956 & 540 & 808 \\
\hline$\theta$ range $\left[{ }^{\circ}\right]$ & $3.80-33.79$ & $2.94-25.06$ & $2.48-25.10$ \\
\hline Measured reflections & 18341 & 11639 & 16156 \\
\hline Independent reflections $/ R_{\text {int }}$ & $3347 / 0.0421$ & $1952 / 0.0374$ & $3235 / 0.0727$ \\
\hline Data/restraints/parameters & $3347 / 0 / 97$ & $1952 / 0 / 130$ & $3235 / 0 / 213$ \\
\hline Goodness of fit on $F^{2}$ & 1.066 & 1.051 & 1.047 \\
\hline$R_{1}[I>2 \sigma(l)]^{[\mathrm{a}]}$ & 0.0517 & 0.0241 & $R_{1}=0.0440$ \\
\hline$w R_{2}$ (all data $)^{[\mathrm{b}]}$ & 0.1338 & 0.0529 & $w R_{2}=0.1099$ \\
\hline Largest diff. peak and hole & 1.272 and -0.456 & 0.372 and -0.265 & 0.448 and -0.378 \\
\hline
\end{tabular}

[a] $R 1=\Sigma|| F_{\mathrm{o}}|-| F_{\mathrm{c}} \| / \Sigma\left|F_{\mathrm{o}}\right|$. [b] $w R_{2}=\left\{\Sigma\left[w\left(F_{\mathrm{o}}{ }^{2}-F_{\mathrm{c}}{ }^{2}\right)^{2}\right] / \Sigma\left[w\left(F_{\mathrm{o}}{ }^{2}\right)^{2}\right]\right\}^{1 / 2}$. 
$\mathrm{Zn}$ " ions are bridged by the $\mu_{4}$ ligands to form a 2D-layered CF with the coordinated DMF molecules arranged between the layers (Figure 3). The coordination motif in CF-2 and CF-3 is very similar to that of previously reported $2 \mathrm{D}$ CF CF-5 $\left\{\left[\mathrm{ZnCl}\left(\mathrm{C}_{8} \mathrm{H}_{4} \mathrm{~N}_{4}\right)_{0.5}\left(\mathrm{C}_{2} \mathrm{H}_{6} \mathrm{O}_{2} \mathrm{~S}\right)\right]\right\}$ formed from 1 and $\mathrm{ZnCl}_{2}$ in DMSO. ${ }^{[5]}$ In CF-5, each Zn" ion forms four coordination bonds, two with $\mathrm{N}$ atoms from two different $\mu_{4}$ ligands, one with a chloride anion and one with an $\mathrm{O}$ atom from methylsulfonylmethane (produced in situ due to the thermal decomposition of DMSO). The methylsulfonylmethane molecules are arranged between the 2D layers formed by the ligands and zinc cations, similarly to the DMF molecules in the crystal structures of CF-2 and CF-3. Due to the larger ligand size in CF-3, additional noncoordinated DMF molecules are located between the 2D layers (two DMF molecules per ligand molecule), as was confirmed by thermogravimetric analysis.
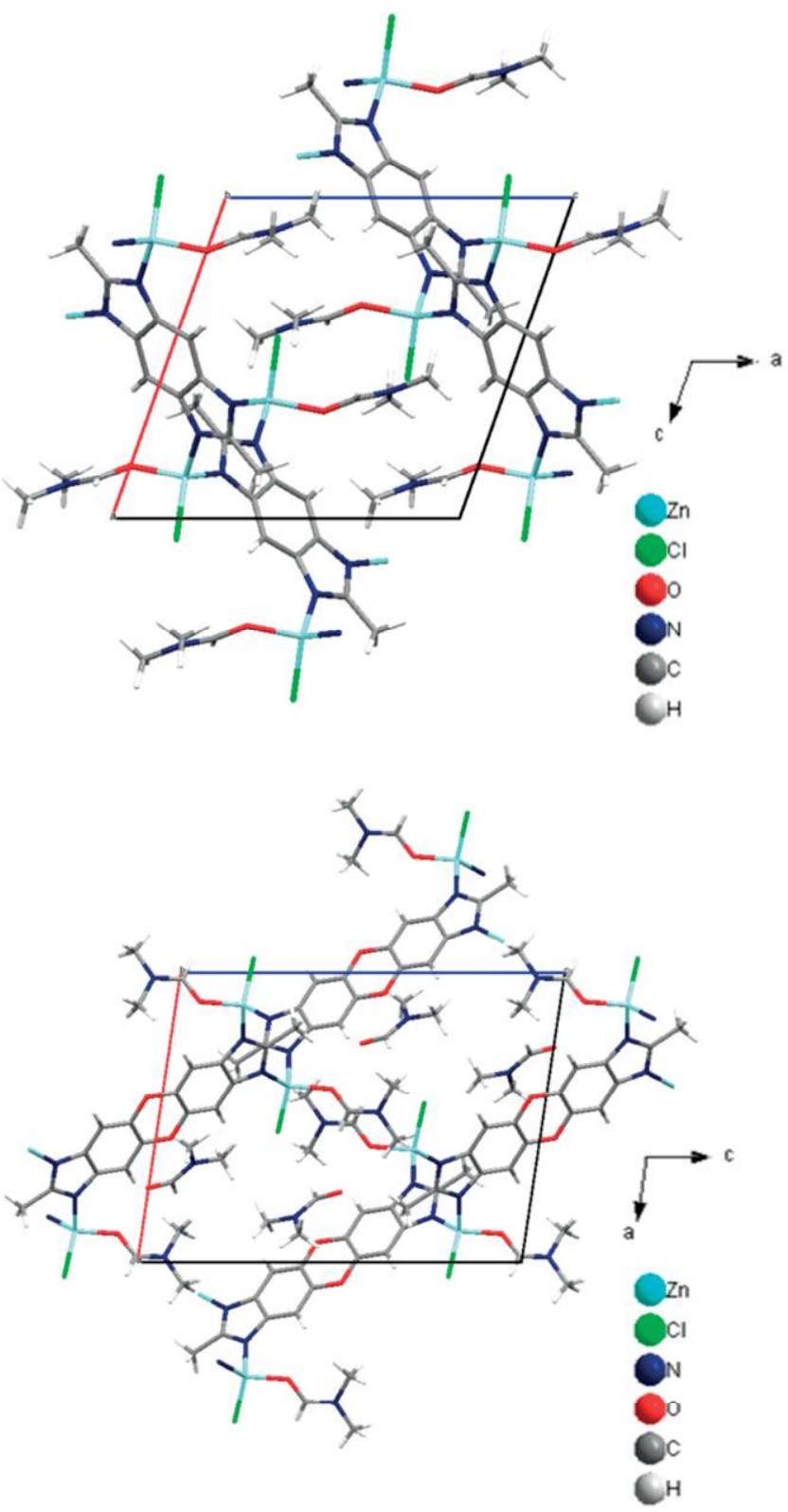

Figure 3. A unit cell of (a) CF-2 and (b) CF-3 displayed in the $b$ direction.

\section{Thermal Stability}

The thermal stabilities of the current frameworks and the reported CFs based on ligand 1 (i.e., $\mathrm{CF}-4^{[6]}$ and $\mathrm{CF}-5^{[5]}$ ) were compared by variable-temperature (VT) XRPD and thermogravimetric analysis (TGA). Ligands $\mathbf{2}$ and $\mathbf{3}$ are stable up to 340 and $400{ }^{\circ} \mathrm{C}$, respectively, as revealed by TGA (Figure S5). By reaction with $\mathrm{Zn}^{\text {Il }}$ ions, CFs with even higher thermal stability were obtained. The TGA of CF-1 revealed two main weigh loss steps (Figure 4a). The first weight loss step of $8.7 \%$ from 100 to $400{ }^{\circ} \mathrm{C}$ can be assigned to the gradual loss of non-coordinated DMSO molecules (calcd. $7.3 \%$ for 0.35 molecules of DMSO in an empirical formula). The structure remains stable up to about $500{ }^{\circ} \mathrm{C}$, above which it decomposes. These findings are in good agreement with the VT-XRPD measurements (Figure $4 \mathrm{~b}$ ), which show that CF-1 remains crystalline up to $450{ }^{\circ} \mathrm{C}$. The slight shifts of the diffraction peaks upon removing the solvent molecules indicate that the solvent could be removed from the framework without altering its structure significantly. The unitcell parameters of the crystalline phase formed upon heating CF-1 to $350{ }^{\circ} \mathrm{C}$ were determined from the XRPD data by using the Dicvol, ${ }^{[10]}$ Treor $^{[11]}$ and ITO ${ }^{[12]}$ programs: $a=13.719(1), b=$ 9.1014(8), $c=12.0536(2) \AA \AA \alpha=90.00, \beta=97.21(8), \gamma=90.00^{\circ}$, $V=1493.2 \AA^{3}$ [Dicvol, M14 = 12, F14 = $17(0.015428,54)$ ]. Additionally, these results also show that CF-1 is much more thermally stable than CF-4, which was reported to be stable only up to $90^{\circ} \mathrm{C}$, and it collapsed when the non-coordinated DMSO molecules were removed from the framework. ${ }^{[6]}$

Void estimation with the PLATON program ${ }^{[13]}$ and the singlecrystal XRD data of CF-1 revealed that the total potentially accessible void volume is $405.3 \AA^{3}$, which corresponds to $25 \%$ of the unit-cell volume $\left(1618.8 \AA^{3}\right)$. Under ambient conditions, these channel voids (Figure S13) are filled with DMSO molecules ( 0.35 molecules in an empirical formula). Upon removing the solvent molecules by heating at $300{ }^{\circ} \mathrm{C}$ under vacuum for $4 \mathrm{~h}$, a nitrogen sorption measurement was carried out, but no significant uptake of $\mathrm{N}_{2}$ at $77 \mathrm{~K}$ was observed. However, this is in agreement with the data obtained from the Poreblazer software analysis, ${ }^{[14]}$ which revealed that CF-1 contains $1 \mathrm{D}$ channels with a pore size of $4.76 \AA$ and a limiting pore diameter of $2.38 \AA$.

Framework CF-2 remains stable during heating up to $220^{\circ} \mathrm{C}$ and then decomposes in two steps, as observed by TGA (Figure 5a). The first weight loss of $27.8 \%$ occurs from 220 to $390{ }^{\circ} \mathrm{C}$ and can be attributed to loss of the two DMF molecules per ligand molecule (calcd. $27.5 \%$ ). The second step begins above $600{ }^{\circ} \mathrm{C}$ and indicates decomposition of the material. The loss of DMF molecules causes a change in the crystal structure of CF2, as observed by VT-XRPD (Figure 5 b). The unit-cell parameters of the new crystalline phase formed when CF-2 was heated to $350{ }^{\circ} \mathrm{C}$ were determined from the XRPD data by using the Dicvol, ${ }^{[10]}$ Treor, $^{[11]}$ and ITO ${ }^{[12]}$ programs: $a=15.184(3), b=$ $10.979(2), c=7.374(1) \AA, \alpha=103.7(2), \beta=89.5(2), \gamma=129.6(1)^{\circ}$, $V=903.5 \AA^{3}$ [Dicvol, M12 = 15.2, F12 = 31.7 (0.0199, 19); no solution in a higher symmetry than the triclinic crystal system was obtained]. Similar behaviour was observed when a sample of CF-3 was heated. The TGA of CF-3 revealed three weight loss steps (Figure $6 \mathrm{a}$ ). The first weight loss of $15.5 \%$ between 100 and $200{ }^{\circ} \mathrm{C}$ can be attributed to the loss of non-coordinated 

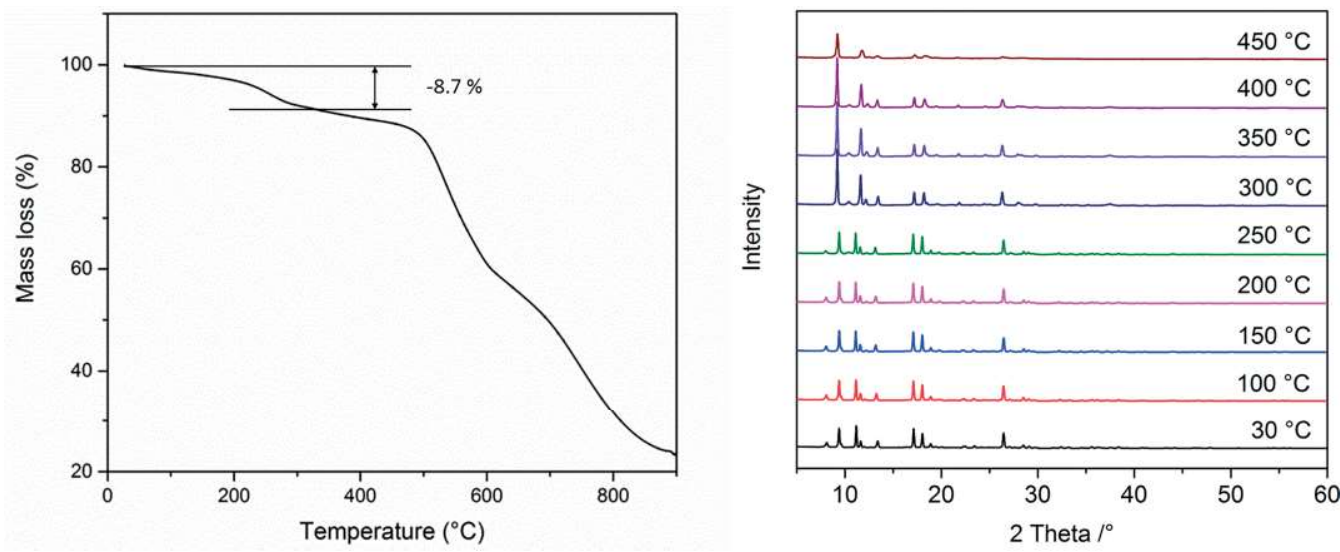

Figure 4. Thermal stability of CF-1 studied by (a) TGA under a nitrogen atmosphere and (b) VT-XRPD in a tightly packed capillary open to air

DMF molecules (calcd. $18.6 \%$ for two DMF molecules per ligand molecule). The second weight loss of $18.6 \%$ occurs between 200 and $300{ }^{\circ} \mathrm{C}$ and is due to the loss of coordinated DMF molecules (calcd. $18.6 \%$ for two DMF molecules per ligand molecule). Above $600{ }^{\circ} \mathrm{C}$, the structure decomposes. The VT-XRPD measurement showed that removing non-coordinated DMF does not influence the crystal structure (Figure 6b). However, above $200{ }^{\circ} \mathrm{C}$, when the coordinated DMF molecules are removed, the crystal structure of CF-3 is altered and it gradually loses its crystallinity. The unit-cell parameters of the new crystalline phase formed when CF-3 was heated to $350{ }^{\circ} \mathrm{C}$ were determined from the XRPD data by using the Dicvol, ${ }^{[10]}$ Treor $^{[11]}$ and $\mathrm{ITO}^{[12]}$ programs: $a=17.558(2), b=11.142(1), c=$ 8.355(1) $\AA, \alpha=90.00, \beta=90.00, \gamma=90.00^{\circ}, V=1630.7 \AA^{3}$ [Dicvol, M10 = 23, F10 = $45(0.018843,12)]$.

The above studies showed some difference in the thermal stability of CF-2 and CF-3 caused by the different sizes of their ligands. Both frameworks change their crystal structure upon
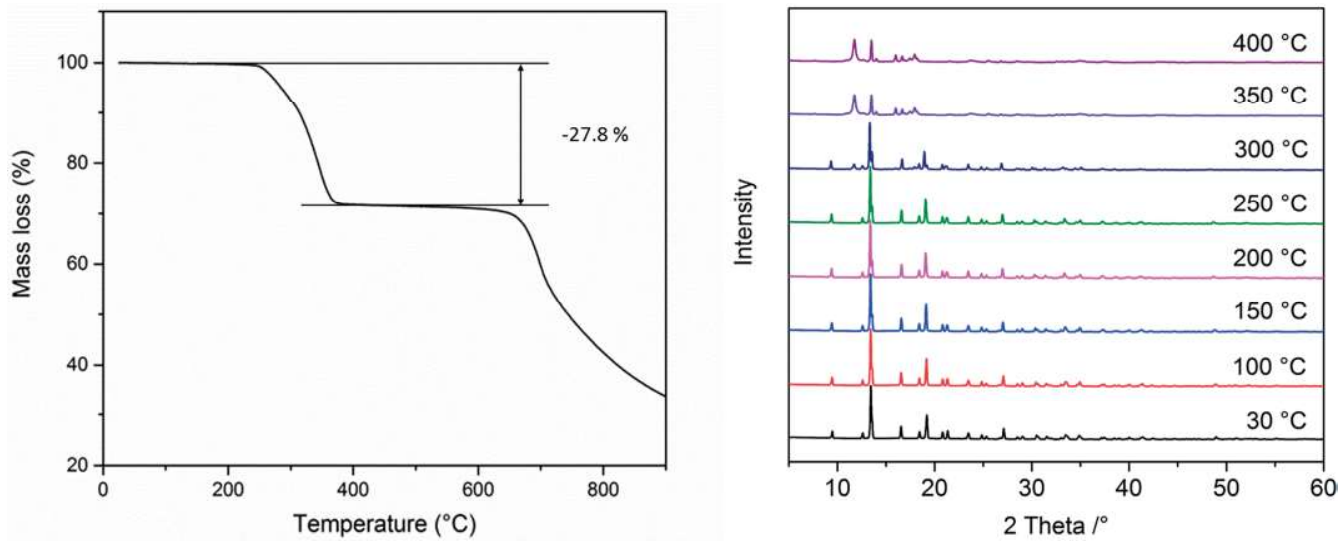

Figure 5. Thermal stability of CF-2 studied by (a) TGA analysis under a nitrogen atmosphere and (b) VT-XRPD in a tightly packed capillary open to air.
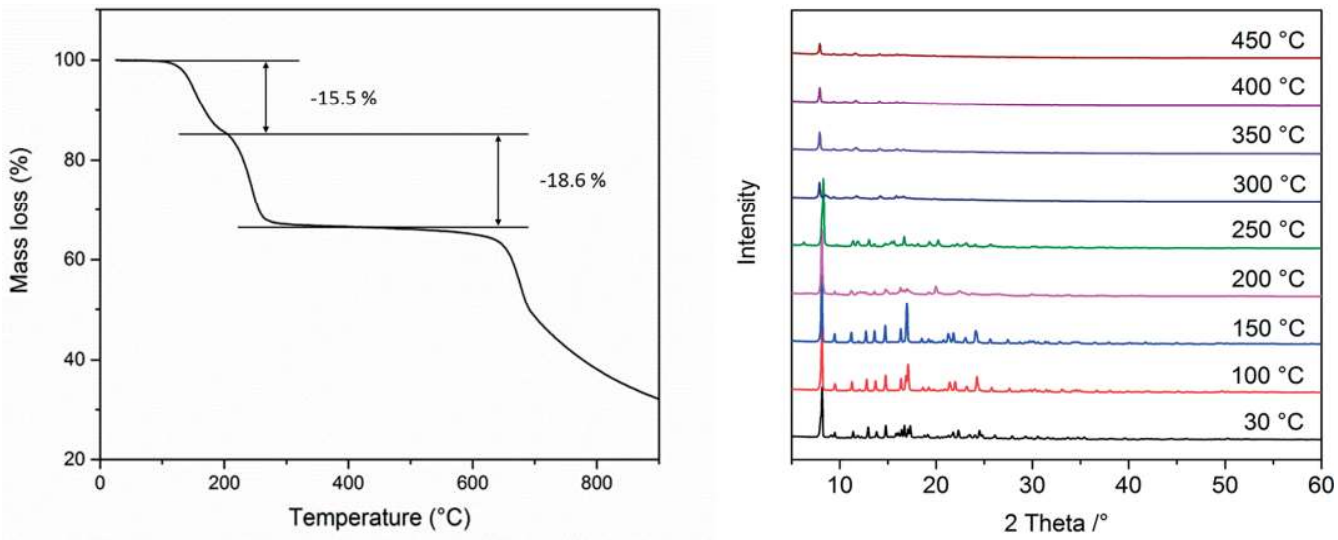

Figure 6. Thermal stability of CF-3 studied by (a) TGA under a nitrogen atmosphere and (b) VT-XRPD in a tightly packed capillary open to air 
removing the coordinated DMF molecules and decompose above $600{ }^{\circ} \mathrm{C}$. However, due to the ligand size, there is space in the crystal structure of CF-3 for non-coordinated DMF molecules (one molecule in an empirical formula), as revealed by single-crystal XRD (Figure 3b) and confirmed by TGA (Figure 6a). Additionally, lower temperature, between only 200 and $300{ }^{\circ} \mathrm{C}$ is needed to remove the coordinated DMF molecules from CF3. To remove the coordinated DMF molecules from CF-2, heating above $300{ }^{\circ} \mathrm{C}$ is needed. Similar thermal behaviour was reported for structurally similar CF-5 $\left\{\left[\mathrm{ZnCl}\left(\mathrm{C}_{8} \mathrm{H}_{4} \mathrm{~N}_{4}\right)_{0.5}\left(\mathrm{C}_{2} \mathrm{H}_{6} \mathrm{O}_{2} \mathrm{~S}\right)\right]\right\}$. The TGA revealed a weight loss between 300 and $370{ }^{\circ} \mathrm{C}$, which was attributed to the loss of coordinated methylsulfonylmethane molecules. ${ }^{[5]}$

\section{Photoluminescence Properties}

The solid-state luminescence properties were investigated at room temperature. Whereas free ligand 3 exhibits only very weak emission and ligand $\mathbf{2}$ is practically non-luminescent, all three CFs CF-1, CF-2 and CF-3 display luminescence in the violet region (Figure 7). Ligand $\mathbf{3}$ exhibits a weak emission band at $393 \mathrm{~nm}\left(\lambda_{\mathrm{ex}}=340 \mathrm{~nm}\right)$, which can be assigned to the intraligand $\pi-\pi^{*}$ transition. Upon excitation of CF-3 at $340 \mathrm{~nm}$, an intense emission band with maximum at $384 \mathrm{~nm}$ was observed. The slight shift of the emission band compared to the free ligand can be attributed to the coordination effect of the $\mathrm{Zn}^{\prime \prime}$ ions to the ligand. CF-1 and CF-2 exhibit similar intense emission bands with maxima at 384 and $375 \mathrm{~nm}$, respectively, upon excitation at 310 and $320 \mathrm{~nm}$, respectively. In addition, the emission spectrum of CF-2 shows one additional broad band centred at $543 \mathrm{~nm}$. The enhancement of the luminescence intensity for CF-1, CF-2 and CF-3 compared to the free ligands is a result of the metal-ligand coordination, which effectively reduces the nonradiative decay of the intraligand $\pi-\pi^{*}$ excited state and possibly enables metal-to-ligand charge transfer between the zinc ions and the ligands. Additional excitation and emission spectra can be found in Figures S6-S8.

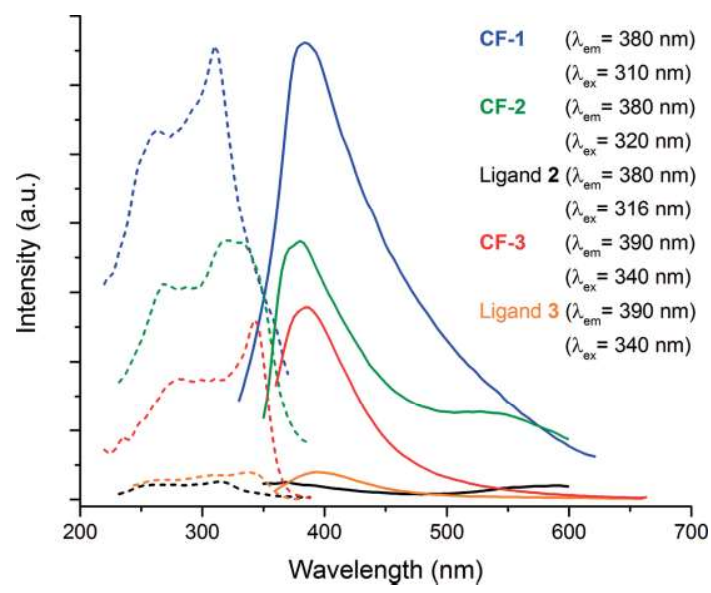

Figure 7. Solid-state luminescence spectra of CF-1, CF-2, CF-3 and free ligands $\mathbf{2}$ and $\mathbf{3}$. Dashed lines: excitation spectra; continuous lines: emission spectra.

\section{Conclusions}

Compounds $\mathbf{2}$ and $\mathbf{3}$, both containing methyl substituents, were synthesized and used as ligands for preparing $\mathrm{Zn}^{\text {II }} \mathrm{CFs}$. Depending on the reaction conditions, compounds $\mathbf{2}$ and $\mathbf{3}$ can be $\mu_{2}$ ligands (e.g., 2 in CF-1) or $\mu_{4}$ ligands if their $\mathrm{NH}$ groups are deprotonated (e.g., $\mathbf{2}$ in CF-2 and $\mathbf{3}$ in CF-3). The compounds were designed to study the influence of the substitution in the 2-position of the imidazole ring on the structure and properties of the resulting CFs. When bisimidazole ligands were mixed with zinc sulfate or zinc nitrate in DMSO, the structure and properties of the final materials were influenced by the presence or absence of the methyl group in the 2-position of the imidazole ligand. If ligand $\mathbf{2}$ was used in the synthesis, 2D CF CF-1 was obtained. Framework CF-1 was found to be thermally more stable than the 3D CF that was obtained when an unsubstituted benzobisimidazole was used. It was also shown that the ligand size was important. Although it did not influence the mode of coordination bonding, it had an influence on the stability of the final material. Framework CF-3 based on the longer ligand $\mathbf{3}$ contains non-coordinated solvent molecules next to the coordinated DMF, and removal of the coordinated solvent molecules required lower temperature compared to the topologically similar CF CF-2, which was prepared starting from ligand 2

Our studies showed that benzobisimidazolates could be used as $\mu_{2}$ and $\mu_{4}$ ligands for preparing CFs and that a small structural change in the substitution of the imidazole unit caused changes in the framework structure and thus influenced the properties of the prepared materials. These findings are in good agreement with observations reported on structurally related ZIFs. Although the presented CFs appear to be nonporous, it might be feasible to prepare truly porous frameworks with potential applications in gas storage and catalysis by using extended bis(2-methylimidazole) ligands. Additionally, the materials exhibit luminescence properties, which together with their very high thermal stability make them, potential candidates for optoelectronic applications.

\section{Experimental Section}

Materials and Methods: All reagents were of analytical grade and used as received from commercial suppliers. FTIR spectra were recorded in the range $4000-400 \mathrm{~cm}^{-1}$ with a Bruker Equinox $55 \mathrm{FTIR}$ spectrometer equipped with an ATR unit. Molecular masses were measured with a Q-Tof Ultima mass spectrometer (Micromass) equipped with an ESI source. ${ }^{1} \mathrm{H}$ and ${ }^{13} \mathrm{C}$ NMR spectra were recorded with a Mercury plus 400 high-resolution system (Variant Deutschland $\mathrm{GmbH}$ ). Luminescence spectra were acquired with a spectrofluorimeter (FS920, Edinburgh Instruments) equipped with a TMS300 monochromator, an 5900 single-photon photomultiplier and an Xe-900 xenon arc lamp ( $450 \mathrm{~W}$ ). The excitation and emission spectra were corrected for the wavelength-dependent lamp intensity and detector response, respectively. TGA was performed with a Netzsch STA 409 PC analyzer in the temperature range of $25-900{ }^{\circ} \mathrm{C}$ under nitrogen atmosphere at a heating rate of $10{ }^{\circ} \mathrm{C} \mathrm{min}-1$. XRPD data were collected at room temperature in the $2 \theta=5-50^{\circ}$ range by using a Seifert XRD 3003 TT powder diffractometer with a Meteor1D detector with $\mathrm{Cu}-K_{\alpha 1}$ radiation $(\lambda=1.54187)$. VT-XRPD data were 
collected with a Bruker D8 ADVANCE $\theta-2 \theta$ diffractometer in transmittance Bragg-Brentano geometry by employing a Göbel mirror, $C$ u radiation and a LYNXEYE 1-D detector. The samples were ground and loaded into quartz capillaries (Hilgenberg) with $0.5 \mathrm{~mm}$ diameter and $0.01 \mathrm{~mm}$ wall thickness. The patterns were recorded in the temperature range of $30-450{ }^{\circ} \mathrm{C}$, in the $2 \theta=3-60^{\circ}$ range with a step time of $1 \mathrm{~s}$ and a step width of $0.02^{\circ}$ in $2 \theta$. Temperature program between measurements: $0.5^{\circ} \mathrm{C} \mathrm{s}^{-1}$ heating rate, followed by $10 \mathrm{~min}$ isothermal steps required for recording diffraction data sets. The sample was exposed to air during the whole measurement. For single-crystal X-ray analysis, crystals of CF-1, CF-2 and CF-3 were taken from mother liquor and mounted on a MiTeGen MicroMounts. The single-crystal XRD data were collected with a Bruker D8 Venture diffractometer. Intensity measurements were performed with monochromated (doubly curved silicon crystal) Mo- $K_{\alpha}$ radiation $(\lambda=0.71073 \AA$ ) from a sealed microfocus tube. Generator settings were $50 \mathrm{kV}, 1 \mathrm{~mA}$. Data collection temperature was $-173^{\circ} \mathrm{C}$. APEX3 software was used for preliminary determination of the unit cell. ${ }^{[15]}$ Determination of integrated intensities and unit-cell refinement were performed with SAINTT. ${ }^{[16]}$ The structure was solved and refined with the Bruker SHELXTL Software Package. ${ }^{[17]}$ Selected crystal data and details of structure refinement for CF-1, CF-2 and CF-3 are provided in Table 1.

CCDC 1570691 (for CF-1), 1570692 (for CF-2) and 1570693 (for CF3) contain the supplementary crystallographic data for this paper. These data can be obtained free of charge from The Cambridge Crystallographic Data Centre.

\section{Ligand Synthesis}

Ligand 2: 1,5-Dihydro-2,6-dimethylbenzo[1,2-d:4,5- $\left.d^{\prime}\right]$ diimidazole (2) was prepared from 1,3-diamino-4,6-diacetamidobenzene (5), which was synthesized from 1,3-diacetamido-4,6-dinitrobenzene (4) according to the procedure reported previously. ${ }^{[7]}$ Compound $\mathbf{5}$ $(1.55 \mathrm{~g}, 6.97 \mathrm{mmol})$ was dissolved in xylene $(50 \mathrm{~mL})$ with acetic acid $(5 \mathrm{~mL})$, and the mixture was heated under reflux for $1 \mathrm{~h}$. After that, the solvents were evaporated and the crude product (brown solid, $1.20 \mathrm{~g}$, yield $92 \%$ ) was purified by Soxhlet extraction with acetone to obtain compound $\mathbf{2}$ as a light beige solid ( $0.96 \mathrm{~g}$, yield $74 \%) .{ }^{1} \mathrm{H}$ NMR (400 MHz, CF $\left.{ }_{3} \mathrm{COOD}\right): \delta=8.14(\mathrm{~s}, 2 \mathrm{H}), 3.00(\mathrm{~s}, 6 \mathrm{H}) \mathrm{ppm} .{ }^{13} \mathrm{C}$ NMR (101 MHz, CF ${ }_{3} \mathrm{COOD}$ ): $\delta=157.2,131.7,101.3,13.6 \mathrm{ppm}$. MS $\left(\right.$ ESI $\left.^{+}\right): m / z 187.10[\mathrm{M}+\mathrm{H}]^{+}$. HR-MS: Calcd. for $\mathrm{C}_{10} \mathrm{H}_{10} \mathrm{~N}_{4}[\mathrm{M}+\mathrm{H}]^{+}$ 187.0978, found 187.0977. IR: $\tilde{v}=1647(w), 1580(w), 1407(\mathrm{~s}), 1226$ $(w), 1044(m), 926(w), 894(m), 866(m), 809(w), 649(s), 562(w)$, $462(w) \mathrm{cm}^{-1}$.

Ligand 3: Compounds $\mathbf{7}$ and $\mathbf{8}$ were prepared according the procedures reported previously. ${ }^{[8]}$ 1,7-Dihydrido-2,8-dimethyl-[1,4]dioxino[2,3-f:5,6- $\left.f^{\prime}\right]$ bisbenzimidazole (3) was prepared by dispersing compound $8(0.515 \mathrm{~g}, 1.32 \mathrm{mmol})$ in acetic acid $(1 \mathrm{~mL})$. The mixture was heated in a microwave synthesizer (CEM, Discover S) at $165^{\circ} \mathrm{C}$ for $4 \mathrm{~h}$ (power $300 \mathrm{~W}$ ). The reaction mixture was cooled and neutralized with a concentrated aqueous solution of $\mathrm{KOH}$. The precipitate was collected by filtration and washed with water to obtain compound 3 as a light beige solid $(0.305 \mathrm{~g}$, yield $79 \%) .{ }^{1} \mathrm{H}$ NMR (400 MHz, CF 3 COOD): $\delta=7.32(\mathrm{~s}, 4 \mathrm{H}), 2.90(\mathrm{~s}, 6 \mathrm{H}) \mathrm{ppm} .{ }^{13} \mathrm{C}$ NMR (101 MHz, CF ${ }_{3} \mathrm{COOD}$ ): $\delta=153.1,144.2,128.9,103.2,13.0$ ppm. MS $\left.(\mathrm{ESI})^{+}\right): m / z 293.21[\mathrm{M}+\mathrm{H}]^{+}, 315.19[\mathrm{M}+\mathrm{Na}]^{+}$. HR-MS: Calcd. for $\mathrm{C}_{16} \mathrm{H}_{12} \mathrm{~N}_{4} \mathrm{O}_{2}[\mathrm{M}+\mathrm{H}]^{+}$293.1033, found 293.1034. IR: $\tilde{v}=2923(\mathrm{w})$, $1639(\mathrm{w}), 1597(\mathrm{~m}), 1550(\mathrm{w}), 1453(\mathrm{~s}), 1419(\mathrm{~m}), 1392(\mathrm{~m}), 1356(\mathrm{~s})$, $1287(\mathrm{~m}), 1219(\mathrm{w}), 1179(\mathrm{~s}), 1099(\mathrm{w}), 1021(\mathrm{~m}), 989(\mathrm{w}), 921(\mathrm{~m})$, $838(\mathrm{~s}), 799(\mathrm{~s}), 669(\mathrm{~m}), 647(\mathrm{~m}), 502(\mathrm{w}), 465(\mathrm{w}), 429(\mathrm{~m}) \mathrm{cm}^{-1}$.

\section{Coordination Framework Synthesis}

$\left\{\left[\mathrm{Zn}\left(\mathrm{SO}_{\mathbf{4}}\right)\left(\mathrm{C}_{\mathbf{1 0}} \mathrm{H}_{\mathbf{1 0}} \mathbf{N}_{\mathbf{4}}\right)\right] \cdot\left(\mathrm{C}_{\mathbf{2}} \mathrm{H}_{\mathbf{6}} \mathrm{OS}\right)_{\mathbf{0 . 3 5}}\right\}$ (CF-1): Method A: $\mathrm{Zn}\left(\mathrm{NO}_{3}\right)_{2}$. $6 \mathrm{H}_{2} \mathrm{O}(113 \mathrm{mg}, 0.38 \mathrm{mmol})$ and ligand $2(24.2 \mathrm{mg}, 0.13 \mathrm{mmol})$ were dissolved in DMSO (4 mL). The solution was placed in a glass heating tube $(10 \mathrm{~mL})$ and heated to $120^{\circ} \mathrm{C}$ for $3 \mathrm{~d}$ and then slowly cooled to room temperature. The colourless leaf-shaped single crystals that formed at the bottom of the heating tube were separated by filtration, washed with DMSO $(3 \times 2 \mathrm{~mL})$ and dried in air to yield CF-1 (6.7 mg, $0.02 \mathrm{mmol}, 12 \%)$. Crystals obtained by this method were used for single-crystal XRD. IR: $\tilde{v}=3127$ (w), 3004 (w), 2878 $(w), 1643(w), 1572(w), 1509(w), 1489(m), 1440(m), 1407(m)$, $1374(\mathrm{w}), 1301(\mathrm{w}), 1146(\mathrm{~s}), 1075(\mathrm{~s}), 1039(\mathrm{~s}), 906(\mathrm{~m}), 859(\mathrm{~m}), 830$ (w), $653(\mathrm{~s}), 633(\mathrm{~s}), 588(\mathrm{~s}), 417(\mathrm{w}) \mathrm{cm}^{-1}$. Method B: For the synthesis in bulk, $\mathrm{ZnSO}_{4} \cdot \mathrm{H}_{2} \mathrm{O}(10 \mathrm{mg}, 0.06 \mathrm{mmol})$ and ligand $2(22 \mathrm{mg}$, $0.12 \mathrm{mmol}$ ) were dissolved in DMSO $(4 \mathrm{~mL})$. The solution was sealed in a glass tube $(10 \mathrm{~mL})$ and heated at $140{ }^{\circ} \mathrm{C}$ for $1 \mathrm{~d}$. The colourless block-shaped crystals were separated by centrifugation, washed with DMSO $(3 \times 1 \mathrm{~mL})$ and dried in air to yield CF-1 $(10.8 \mathrm{mg}$, $0.03 \mathrm{mmol}, 24 \%$ ). This reaction procedure was used to obtain samples for TGA, VT-XRPD and sorption measurements. IR: $\tilde{v}=3126(\mathrm{w})$, $2998(w), 2876(w), 2818(w), 1641,(w), 1573(m), 1493(m), 1438$ $(\mathrm{m}), 1406(\mathrm{~m}), 1302(\mathrm{w}), 1147(\mathrm{~s}), 1074(\mathrm{~s}), 1040(\mathrm{~s}), 905(\mathrm{~m}), 861$ $(\mathrm{m}), 832(\mathrm{~m}), 654(\mathrm{~m}), 634(\mathrm{~m}), 587(\mathrm{~m}), 416(\mathrm{w}) \mathrm{cm}^{-1}$

$\left\{\left[\mathrm{ZnCl}\left(\mathrm{C}_{10} \mathbf{H}_{\mathbf{8}} \mathbf{N}_{\mathbf{4}}\right)_{\mathbf{0} .5}\left(\mathrm{C}_{\mathbf{3}} \mathrm{H}_{7} \mathrm{NO}\right)\right]\right\}$ (CF-2): Anhydrous $\mathrm{ZnCl}_{2}(58.5 \mathrm{mg}$, $0.43 \mathrm{mmol})$, ligand $2(10 \mathrm{mg}, 0.05 \mathrm{mmol})$ and DMF $(3 \mathrm{~mL})$ were placed in a glass heating tube $(10 \mathrm{~mL})$. The mixture was heated at $130^{\circ} \mathrm{C}$ for $3 \mathrm{~d}$. Large, colourless, leaf-shaped crystals were obtained. The crystals were separated by filtration, washed with DMF $(3 \times$ $1 \mathrm{~mL}$ ) and dried in air to yield CF-2 (17 mg, $0.03 \mathrm{mmol}, 59 \%)$. IR: $\tilde{v}=2928(\mathrm{w}), 1656(\mathrm{~s}), 1489(\mathrm{~m}), 1421(\mathrm{~s}), 1373(\mathrm{~s}), 1251(\mathrm{~s}), 1228$ $(\mathrm{m}), 1170(\mathrm{~s}), 1121(\mathrm{~s}), 1063(\mathrm{~m}), 1012(\mathrm{~m}), 917(\mathrm{~s}), 861(\mathrm{~s}), 690(\mathrm{~s})$, $674(\mathrm{~s}), 640(\mathrm{~m}), 508(\mathrm{~m}), 433(\mathrm{~m}) \mathrm{cm}^{-1}$.

$\left\{\left[\mathrm{ZnCl}\left(\mathrm{C}_{16} \mathrm{H}_{10} \mathrm{~N}_{4} \mathrm{O}_{2}\right)_{0.5}\left(\mathrm{C}_{3} \mathrm{H}_{7} \mathrm{NO}\right)\right] \cdot\left(\mathrm{C}_{3} \mathrm{H}_{7} \mathrm{NO}\right)\right\} \quad(\mathrm{CF}-3):$ Anhydrous $\mathrm{ZnCl}_{2}(37 \mathrm{mg}, 0.27 \mathrm{mmol})$, ligand $3(10 \mathrm{mg}, 0.03 \mathrm{mmol})$ and DMF $(3 \mathrm{~mL})$ were placed in a glass heating tube $(10 \mathrm{~mL})$. The mixture was heated at $130^{\circ} \mathrm{C}$ for $3 \mathrm{~d}$. Large, colourless, leaf-shaped crystals were obtained. The crystals were separated by filtration, washed with DMF $(3 \times 1 \mathrm{~mL})$ and dried in air to yield CF-3 $(15 \mathrm{mg}$, $0.04 \mathrm{mmol}, 45 \%)$. IR: $\tilde{v}=2929,(\mathrm{w}), 1659(\mathrm{~s}), 1583(\mathrm{~m}), 1474(\mathrm{~m})$, $1445(\mathrm{~s}), 1388(\mathrm{~s}), 1358(\mathrm{~s}), 1318(\mathrm{~m}), 1255(\mathrm{~m}), 1186(\mathrm{~s}), 1123(\mathrm{~m})$, $1091(\mathrm{~m}), 1065(\mathrm{~m}), 1009(\mathrm{~m}), 934(\mathrm{~s}), 864(\mathrm{~s}), 807(\mathrm{~s}), 695(\mathrm{~s}), 680$ (s), $660(\mathrm{~m}), 519(\mathrm{~m}), 470(\mathrm{~m}), 538(\mathrm{~m}), 420(\mathrm{~m}) \mathrm{cm}^{-1}$.

\section{Acknowledgments}

H. B. is grateful to the program "Chancengleichheit für Frauen in Forschung und Lehre" from the University of Augsburg for financial support via a fellowship.

Keywords: Zinc · N ligands · Metal-organic frameworks . Ligand effects · Zeolite analogues

[1] a) K. S. Park, Z. Ni, A. P. Côté, J. Y. Choi, R. Huang, F. J. Uribe-Romo, H. K. Chae, M. O'Keeffe, O. M. Yaghi, Proc. Natl. Acad. Sci. USA 2006, 103, 10186-10191; b) A. Phan, C. J. Doonan, F. J. Uribe-Romo, C. B. Knobler, M. O'Keeffe, O. M. Yaghi, Acc. Chem. Res. 2010, 43, 58-67; c) J.-P. Zhang, Y.-B. Zhang, J.-B. Lin, X.-M. Chen, Chem. Rev. 2012, 112, 1001-1033.

[2] a) B. Chen, Z. Yang, Y. Zhu, Y. Xia, J. Mater. Chem. A 2014, 2, 1681116831 ; b) B. R. Pimentel, A. Parulkar, E. Zhou, N. A. Brunelli, R. P. Lively, ChemSusChem 2014, 7, 3202-3240.

[3] For instance: a) W. Lu, Z. Wei, Z.-Y. Gu, T.-F. Liu, J. Park, J. Park, J. Tian, M. Zhang, Q. Zhang, T. Gentle III, M. Boscha, H.-C. Zhou, Chem. Soc. Rev. 2014, 43, 5561-5593; b) M. Zhang, M. Bosch, T. Gentle III, H.-C. Zhou, CrystEngComm 2014, 16, 4069-4083; c) M. O'Keeffe, O. M. Yaghi, Chem. Rev. 2012, 112, 675-702; d) D. J. Tranchemontagne, J. L. Mendoza-Cortés, 
M. O'Keeffe, O. M. Yaghi, Chem. Soc. Rev. 2009, 38, 1257-1283; e) M. Eddaoudi, J. Kim, N. Rosi, D. Vodak, J. Wachter, M. O'Keeffe, O. M. Yaghi, Science 2002, 295, 469-472.

[4] D.-D. Zhou, C.-T. He, P.-Q. Liao, W. Xue, W.-X. Zhang, H.-L. Zhou, J.-P. Zhang, X.-M. Chen, Chem. Commun. 2013, 49, 11728-11730.

[5] X. Yin, H. Chen, Y. Song, Y. Wang, Q. Li, L. Zhang, J. Colloid Interface Sci. 2014, 413, 175-182

[6] S. Biswas, Y.-Y. Liu, M. Tonigold, M. Weil, D. Volkmer, Eur. J. Inorg. Chem. 2014, 5362-5369.

[7] a) H. Hart, D. Ok, J. Org. Chem. 1986, 51, 979-986; b) M. D. Coburn, J. K. Berlin, Synthesis 1974, 869-870; c) J. H. Boyer, R. S. Buriks in: Organic Syntheses, Wiley, New York, 1973, pp. 1067

[8] a) D. Denysenko, M. Grzywa, M. Tonigold, B. Streppel, I. Krkljus, M. Hirscher, E. Mugnaioli, U. Kolb, J. Hanss, D. Volkmer, Chem. Eur. J. 2011, 17,
1837-1848; b) K. Chichak, U. Jacquemard, N. R. Branda, Eur. J. Inorg. Chem. 2002, 357-368.

[9] A.-C. Yang, T.-Y. Wang, C.-A. Daia, D.-Y. Kang, CrystEngComm 2016, 18, 881-887.

[10] A. Boultif, D. Louer, J. Appl. Crystallogr. 2004, 37, 724-731.

[11] P.-E. Werner, L. Eriksson, M. Westdahl, J. Appl. Crystallogr. 1985, 18, $367-$ 370

[12] J. W. Visser, J. Appl. Crystallogr. 1969, 2, 89-95.

[13] A. L. Spek, Acta Crystallogr., Sect. D 2009, 65, 148-155.

[14] L. Sarkisov, Mol. Simul. 2011, 37, 1248-1257.

[15] APEX3 Version 2016.9, Bruker AXS Inc.

[16] SAINT Version 8.37A, 2015, Bruker AXS Inc

[17] XL Version 2016; G. M. Sheldrick, Acta Crystallogr., Sect. C 2015, 71, 3-8. 